\title{
ANALYSIS OF GROUNDWATER LEVEL CHANGES IN CLEARCUTTING AREA OF CHOSEN FOREST HABITATS
}

\author{
Rafał Stasik ${ }^{1}$, Mariusz Korytowski ${ }^{1}$ \\ 1 Institute of Land Reclamation, Environmental Development and Geodesy, Poznań University of Life Science, \\ Piątkowska 94E, 60-694 Poznań, Poland, e-mail: stasikr@up.poznan.pl; mario@up.poznan.pl
}

Received: 2015.06.06 Accepted: 2015.08.31 Published: 2015.10.01

\begin{abstract}
Changes of the groundwater levels in the area of clearcutting in a swampy habitat and moist mixed broadleaved forest are analysed in the paper. The aim of the research is to evaluate the influence of clearcutting on the amount of changes in groundwater levels. The research was carried out in two forestries located on the southern tip of Greater Poland, belonging to Siemianice Experimental Forest Farm. The analysis is based on data from wells located in ash-alder swamp forest in Marianka forestry and moist broadleaved forest in Laski forestry. The research is based on the relation of groundwater levels in wells located in clearcutting and observation wells. The received relationship of groundwater levels helps estimate changes in groundwater table, depending on its depth before clearcutting. The research shows increases of groundwater levels in the area of clearcutting. Increments are significantly higher in moist broadleaved forest than in ash-alder swamp forest.
\end{abstract}

Keywords: groundwater, clearcutting, forest site types.

\section{INTRODUCTION}

According to forests act [Dziennik Ustaw... $2014]$ the statutory duty of the National Forest Holding "State Forests" is carrying out sustainable forest management aimed at preserving sustainability of forests and enhancement of forest resources and the continuity of their multilateral use. According to the data from the Report on the condition of forests in Poland in 2013 [Raport... 2014], $48.8 \%$ of the area is forested with a dominant economic function. Therefore, due to economic nature of forests, there is a need to create clearcuttings. Clearcuttings, which are artificial disturbances in the forest environment are single cut downs, ie. a complete cut down of all trees of mature tree stand, intended to be removed during its renewal [Jaszczak 1999]. Creating of clearcutting changes abiotic conditions, availability of nutrients, by definition disrupts the functioning of ecosystems, groups or population [Sławska 2006, Sławski 2006]. On the surface covered by clearcutting may occur many, sometimes very abrupt changes. As a result of the relatively rapid reduction of biomass in a large open area of the clearcutting the amount of radiation reaching the soil is increased [McCaughey 1985], which affects, among other things, the increase of soil temperature [Radler et al. 2010]. So rapid changes have also their influence on water management in the area of clearcutting causing, among others, the increase of outflows in catchments [Swank 2001, Moore 2005]. Because of the reduced interception and evapotranspiration in the area covered by the clearcutting, the increase of groundwater table is occurred [Trousdell \& Hoover 1955, Hott 2010, Finnegan 2014]. On the other hand, Henriksen and Kirkhusmo [2000] point out, that the increase of groundwater levels may be caused by higher precipitation. The amount of groundwater levels changes in the clearcutting area of chosen forest habitats is analysed in the paper.

\section{MATERIALS AND METHODS}

The results of the research carried out in two small catchments in hydrological years 2000-2011 are used in the paper. First one is a catchment of 
Rakowski ditch, named on maps as ditch G, situated in Marianka Forestry, and pond catchment no. 5, situated in Laski forestry (Figure 1). Both forestries are part of Siemianice Experimental Forest Farm (LZD) belonging to Poznan University of Life Sciences. According to Kondracki's Geografia Regionalna Polski [Regional Geography of Poland 1998] LZD Siemianice Forests are situated in the area of Wysoczyzna Wieruszows$\mathrm{ka}$. This area is located in the southern part of the Południowowielkopolska lowland and is at the same time its southern border. In terms of hydrographic the object lies in the catchment area of the river Pomianki, which is a left tributary Prosna. According to the regionalization of natural-forest, forests in this area are located in the north-eastern part of mesoregion Oleśnicka Plain V natural-forest land [Kraina Śląska]. Ditch $\mathrm{G}$ has a catchment area of $3.27 \mathrm{~km}^{2}$ and its forest cover is $65 \%$. A characteristic feature of this catchment is a significant share of wetland habitats, which represent a total of $50.6 \%$ of the forest area catchment. No. 5 pond catchment has an area of approximately 20 hectares and is $100 \%$ forest catchment, in which dominate fresh habitats. In the field directly adjacent to the pond there is a moist broadleaved forest habitat and moist mixed broadleaved forest habitat.
For the analysis of groundwater levels changes in Rakowski ditch catchment (G), wells 4.3, 4.4 located on ash-alder swamp forest habitat in the area of clearcutting have been chosen. Clearcutting was made in August and September 2005. As a result of it, from the surface of $1.76 \mathrm{ha}$, $405.24 \mathrm{~m}^{3}$ of timber, mainly of black alder have been harvested. For comparison, control wells 4.2 and 4.5 , located on moist mixed coniferous forest were used (Figure 1). Distance from well 4.4 to well 4.5 is $30 \mathrm{~m}$, and from well 4.3 to well 4.2 is $54 \mathrm{~m}$. In pond catchment no. 5 , data from measurements of groundwater levels in wells 1.1 and 1.2 on moist mixed forest habitat were used for analysis. Clearcutting was made on a surface of 1.77 ha of moist mixed broadleaved forest in period from February to October $2006.444 .51 \mathrm{~m}^{3}$ of timber have been acquired in total. The clearcutting also included fragments of land on adjacent habitats of moist broadleaved forest and fresh broadleaved forest, and also beyond the border of pond catchment no.5, where it was made on a surface of 4.59 ha. To estimate groundwater levels changes, control well 1.3 located in a fresh broadleaved forest habitat, $160 \mathrm{~m}$ from well 1.2 and $170 \mathrm{~m}$ from well 1.1 was used.

The research included systematic measurements of ground water levels in selected wells,

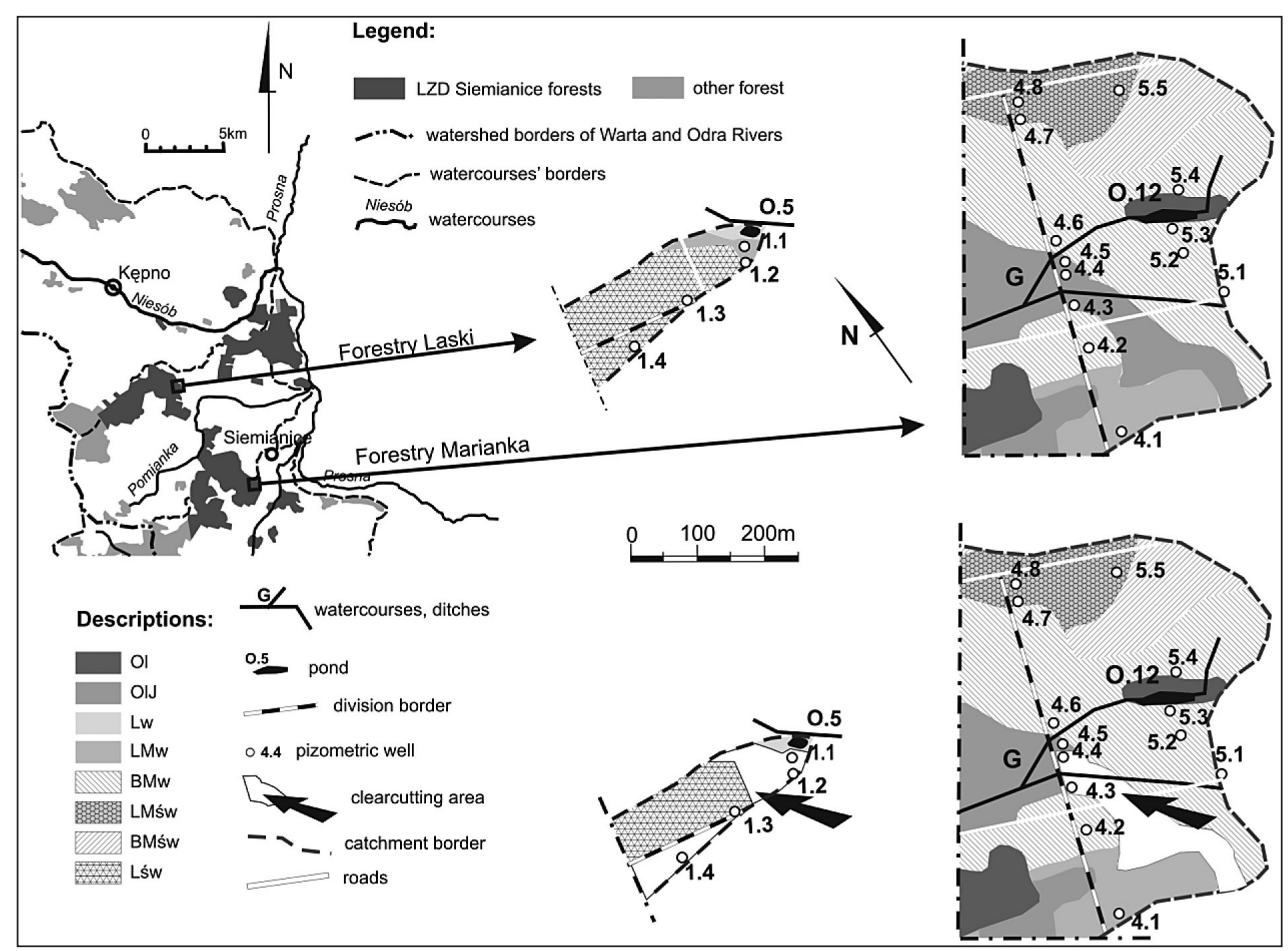

Figure 1. Location and forest habitat maps of analysed parts of Rakowski ditch and pond no. 5. Descriptions of forest site types: $\mathrm{Ol}$ - alder carr forest, OlJ - ash-alder swamp forest, $\mathrm{Lw}$ - moist broadleaved forest, $\mathrm{LMw}$ - moist mixed broadleaved forest, BMw - moist mixed coniferous forest, LMśw - fresh mixed broadleaved forest, BMśw - fresh mixed coniferous forest 
conducted at a frequency of once a week in the hydrological years 2000-2004. In wells 4.2, 4.3, $4.4,4.5$, in a hydrological years 2005-2010, the measurements were conducted at a frequency once in two weeks. Evaluation of groundwater levels changes as a result of clearcutting is based on linear regression analysis of a relation between groundwater levels in wells of clearcutting (4.3, $4.4,1.1,1.2)$ and levels in control wells $(4.2,4.5$, 1.3). This allows make the results independent from the possible impact of meteorological conditions. Relations for wells 4.3 and 4.2 , and 4.4 and 4.5 in ditch $G$ catchment were determined before clearcutting (2000-2005), after clearcutting (2006-2010). For wells 1.1, 1.2, 1.3 in pond catchment no.5 relations of groundwater levels were calculated for period before clearcutting (2000-2006) and after clearcutting (2007-2011). Soil-habitat maps [Operat... 1999], general maps and tree stand forest valuation [Plan urządzania 1994] designed for LZD Siemianice were used in the paper. Soil texture was determined by Casagrande's areometric method modificated by Prószyński according to PN-R-04033 "Gleby i utwory mineralne - podział na frakcje i grupy granulometryczne", carried out on samples with the inviolable structure in selected soil profiles. According to the USDA the names of textural class were presented in the paper.

\section{RESULTS}

In the upper layers of the soil profile at the location of the well 4.3, under a layer of sandy muck, granulometric composition includes loamy sands, passing at a depth of about $20 \mathrm{~cm}$ in sandy loam and deeper into the loam. Soil profile of

a)

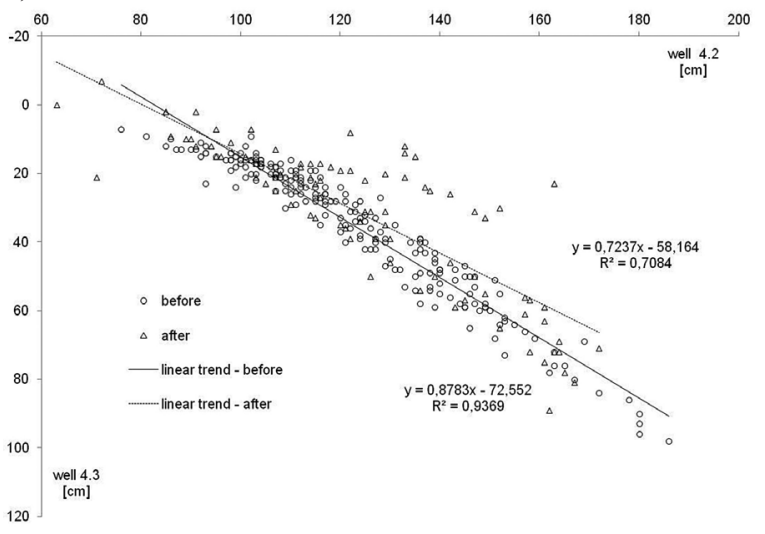

well 4.2 , control relative to 4.3 is also built with sandy muck, which at the depth of $7 \mathrm{~cm}$ changes into a sand. In 4.4 well profile in the upper layers occurs muck, deeper sandy loam at a depth approximately $60 \mathrm{~cm}$ change into silt and sand. Soil profile of well 4.5, assumed as a control for well 4.4 is totally built with sands. 1.2 well soil profile in the upper layer is built with sandy loam lying approximately $55 \mathrm{~cm}$ at loamy sand and deeper at sandy loam and clay. 1.2 profile consisted completely of sand. In a 1.3 well soil profile, control for two others in Laski forestry, in the upper layer there is a sandy loam, which is located approx. $50 \mathrm{~cm}$ at loamy sand that changes into sand at the depth of $70 \mathrm{~cm}$.

The two values presented in Figure 2 determination coefficients of regression equations show that relationship between groundwater levels in wells 4.3 and 4.4 and water level in control wells before clearcutting was significant at a significance level $\mathrm{a}=0.05$. The trend lines indicate that in the area of clearcutting, the groundwater table was raised. The size of water table increment was however, not the same in the all depth, and became higher along with it. Mileage of trend line indicates that a slight decrease of groundwater table at the clearcutting at a time when it is in arrears directly on the surface of the land is possible too.

Furthermore, the lower coefficients of determination for relations of water levels after clearcutting in comparison to the period before clearcutting indicate that tree stands affect stabilizing these relationships. That is also showed by more spread points around the trend line in a period after clearcutting. For relations of groundwater levels in the area of clearcutting in wells 1.1 and 1.2 with the control well 1.3 in Laski

b)

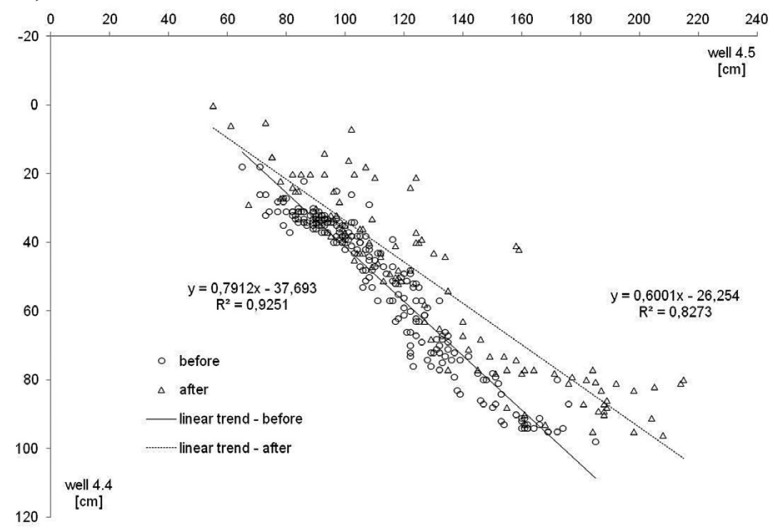

Figure 2. Correlation of groundwater levels [cm] in well 4.3 and 4.4 with groundwater in controlling wells 4.2 and 4.5 in hydrological years before (2000-2005) and after (2006-2010) clearcutting 
a)

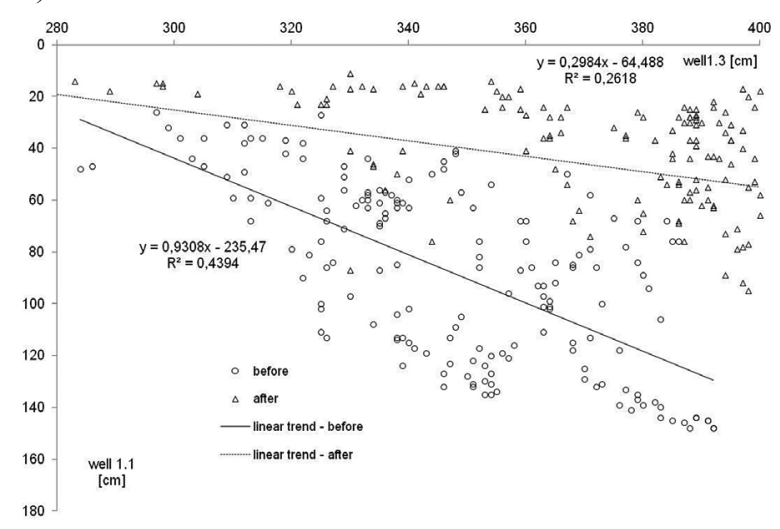

b)

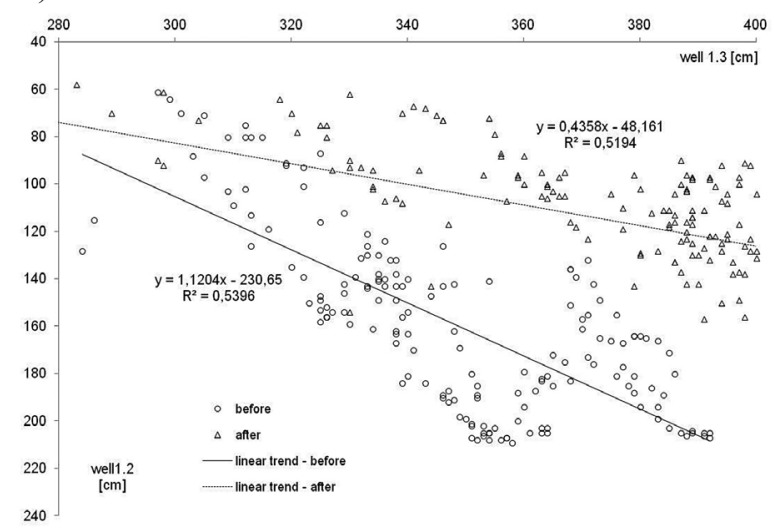

Figure 3. Correlation of groundwater levels [cm] in well 1.1 and 1.2 with groundwater in controlling well 1.3 in hydrological years before (2000-2006) and after (2007-2011) clearcutting

forestry the obtained relations were also statistically significant, however, coefficients of determination were lower. When it comes to relations between groundwater levels in wells 1.1 and 1.3 after clearcutting in comparison to the period before it, coefficients of determination were significantly lower, while for relations between wells 1.2 and 1.3 difference in the size of coefficients in the period before and after clearcutting was not as big. Comparing diagrams of these relations in Figures 2 and 3, it could be noticed, that raise of the level of groundwater table in wells 1.1 and 1.2 in moist broadleaved forest in Laski forestry was much higher than in wells 4.3 and 4.4 in ash-alder swamp forest in Marianka forestry.

Based on regression equations, absolute and relative water levels increases in wells in the area of clearcutting, depending on the depth were calculated. Calculations for particular wells were made for the groundwater levels in the scope of their occurrence before clearcutting. Hence, adopted scope of groundwater levels for wells 4.3 and 4.4 from the ground to a depth about $100 \mathrm{~cm}$ was from 20 to $160 \mathrm{~cm}$ and for wells 1.1 and 1.2 from 60 to $220 \mathrm{~cm}$. The results of these calculations are presented in Tables 1 and 2.

Calculations based on regression equations before and after clearcutting confirmed the link, which could be seen in diagrams (Figure 2), that in wells 4.3 and 4.4 the size of groundwater levels increases with the depth before clearcutting. The biggest increases of groundwater levels in the clearcutting were observed at the deepest depth $(100 \mathrm{~cm})$, where they were around $16 \mathrm{~cm}$ in well 4.3 (16\% increase) and $22 \mathrm{~cm}$ in well $4.4(22 \%$ increase). Calculations for a depth of about $10 \mathrm{~cm}$ for both wells indicate that there is no groundwa- ter level increase in this area, after clearcutting. However, at the surface, groundwater levels in the ash-alder swamp forest habitat, where wells 4.3 and 4.4 are located, because of the clearcutting, may decrease slightly. As showed by research conducted by Dube [1995], in habitats where the water table before clearcutting was really close to the surface of land, because of clearcutting, it may occur groundwater level decrease due to increased evaporation from the soil surface. The analysed swamp ash-alder habitats, where groundwater is near surface of land can be undoubtedly included to that kind of habitats [Kosturkiewicz et al. 2001, 2002].

In Laski forestry in moist mixed broadleaved forest, groundwater level increases after clearcutting for the deepest groundwater table $(160 \mathrm{~cm}$ in well 1.1 and $220 \mathrm{~cm}$ in well 1.2 ) were $98 \mathrm{~cm}$ and $93 \mathrm{~cm}$. This corresponded to a relative increments of respectively $61 \%$ and $42 \%$. Together with decreasing of depth calculated groundwater levels increments after clearcutting became reduced too. In wells 1.1 and 1.2 in moist broadleaved forest_both absolute and relative increases of groundwater levels were significantly higher (Table 2) compared with the increments in wells of 4.3 and 4.4 in ash-alder swamp forest in Marianka forestry (table 1). For example, at a depth of $100 \mathrm{~cm}$ groundwater in moist mixed forest habitat increased twice higher than in the habitat of ashalder swamp forest habitat.

Such differentiation of increases in water levels after the clearcutting may be due to higher values of actual evapotranspiration for the moist mixed forest habitats compared to the ash-alder swamp forest habitat. According to data obtained from Siemianice, in the area covered by clearcut- 
Table 1. Groundwater level changes in well 4.3 and 4.4 before and after clearcutting

\begin{tabular}{|c|c|c|c|c|c|c|c|}
\hline \multicolumn{4}{|c|}{ St. 4.3} & \multicolumn{4}{c|}{ St. 4.4 } \\
\hline \multicolumn{2}{|c|}{ Groundwater level [cm] } & \multicolumn{2}{|c|}{ Increase } & \multicolumn{2}{c|}{ Groundwater level [cm] } & \multicolumn{2}{c|}{ Increase } \\
\hline before & after & {$[\mathrm{cm}]$} & {$[\%]$} & before & after & {$[\mathrm{cm}]$} & {$[\%]$} \\
\hline 0 & 2 & -2 & - & 0 & 3 & -3 & - \\
\hline 10 & 10 & 0 & 0 & 10 & 10 & 0 & +3 \\
\hline 20 & 18 & +2 & +9 & 20 & 18 & +3 & +12 \\
\hline 30 & 27 & +4 & +12 & 30 & 25 & +5 & +16 \\
\hline 40 & 34 & +5 & +14 & 40 & 33 & +7 & +19 \\
\hline 50 & 42 & +7 & +14 & 50 & 40 & +10 & +20 \\
\hline 60 & 51 & +9 & +15 & 60 & 48 & +12 & +21 \\
\hline 70 & 59 & +11 & +15 & 70 & 55 & +15 & +21 \\
\hline 80 & 68 & +13 & +16 & 80 & 63 & +17 & +22 \\
\hline 90 & 76 & +14 & +16 & 90 & 70 & +19 & +22 \\
\hline 100 & 84 & +16 & +16 & 100 & 78 & +22 & +22 \\
\hline
\end{tabular}

Table 2. Groundwater level changes in well 1.1 and 1.2 before and after clearcutting

\begin{tabular}{|c|c|c|c|c|c|c|c|}
\hline \multicolumn{4}{|c|}{ St. 1.1} & \multicolumn{4}{|c|}{ St. 1.2} \\
\hline \multicolumn{2}{|c|}{ Groundwater level $[\mathrm{cm}]$} & \multicolumn{2}{|c|}{ Increase } & \multicolumn{2}{|c|}{ Groundwater level $[\mathrm{cm}]$} & \multicolumn{2}{|c|}{ Increase } \\
\hline before & after & {$[\mathrm{cm}]$} & {$[\%]$} & before & after & {$[\mathrm{cm}]$} & {$[\%]$} \\
\hline 20 & 17 & +3 & +12 & 60 & 64 & -4 & -8 \\
\hline 30 & 21 & +9 & +31 & 70 & 68 & +2 & +2 \\
\hline 40 & 24 & +16 & +40 & 80 & 72 & +8 & +10 \\
\hline 50 & 27 & +23 & +46 & 90 & 76 & +14 & +15 \\
\hline 60 & 30 & +30 & +49 & 100 & 80 & +20 & +20 \\
\hline 70 & 33 & +37 & +52 & 120 & 88 & +32 & +27 \\
\hline 80 & 37 & +43 & +54 & 140 & 96 & +44 & +32 \\
\hline 90 & 40 & +50 & +56 & 160 & 103 & +57 & +35 \\
\hline 100 & 43 & +57 & +57 & 180 & 111 & +69 & +38 \\
\hline 120 & 50 & +70 & +59 & 200 & 119 & +81 & +41 \\
\hline 140 & 56 & +84 & +60 & 220 & 127 & +93 & +42 \\
\hline 160 & 62 & +98 & +61 & & & & \\
\hline
\end{tabular}

ting in ash-alder swamp forest in Marianka forestry the volume of wood harvested per area unit amounted to $230.25 \mathrm{~m}^{3} \cdot \mathrm{ha}^{-1}$, and in Laski forestry in the area of clearcutting covered by a moist mixed forest $250.13 \mathrm{~m}^{3} \cdot \mathrm{ha}^{-1}$, which could also contribute to this variation. In addition, it may result from the diversity of physiographic parameters of catchment area or from different habitats supplying of these waters that flow from adjacent areas as well from the fact that in the area adjacent to the clearcutting in mixed forest habitat the clearcutting was also made in the area of over 4.5 ha. Groundwater levels increase in the adjacent area could affect the groundwater in the area of the researched clearcutting. This hypothesis, however, required to take further, more detailed studies and analyzes.

\section{CONCLUSIONS}

1. The regression equations for the relations of groundwater levels in the habitats of ash-alder swamp forest and moist mixed broadleaved forest calculated for a period before and after clearcutting showed a rise in the water table as a result of carrying out clearcuttings.

2. The size of increases of groundwater levels of both analyzed surfaces was related to the depth of the groundwater before the clearcutting. Both absolute and relative rise in the groundwater table was higher for the waters that before clearcutting filled deeper, in comparison with groundwater remaining closer to the ground surface. 
3. The study also showed that in the ash-alder swamp forest habitat in Marianka forestry increases of groundwater levels due to clearcutting were significantly lower compared with increments of groundwater levels in the habitat of moist broadleaved forest habitat in Laski forestry.

4. The difference in size increments of groundwater levels in both habitats might be caused by variations in the evapotranspiration the diversification of physiographic conditions, or the size of the power supply of groundwater from the above areas and adjacent areas. Confirmation of these hypotheses, however, require a further detailed study.

\section{REFERENCES}

1. Dubé S., Plamondon A.P. 1995. Relative importance of interception and transpiration changes causing watering-up after clearcutting on four wet sites. Man's Influence on Freshwater Ecosystems and Water Use [Proceedings of a Boulder Symposium, July 1995]. IAHS Publ. no. 230, 113-120.

2. Dubé S., Plamondon A.P., Rothwell R.L. 1995. Watering-up after clear-cutting on forested wetlands of the St Lawrence lowland. Water Resources Research, 31(7), 1741-1750.

3. Dziennik Ustaw Rzeczypospolitej Polskiej, Warszawa, dnia 1 września 2014 r., pos. 1153, pp. 26.

4. Finnegan J., Regan J.T., Fenton O., Lanigan G.J., Brennan R.B., Healy M.G. 2014. The short-term effects of management changes on watertable position and nutrients in shallow groundwater in a harvested peatland forest. Journal of Environmental Management 142, 46-52.

5. Hotta N., Tanaka N., Sawano S., Kuraji K., Shiraki K., Suzuki M. 2010. Changes in groundwater level dynamics after low-impact forest harvesting in steep, small watersheds. Journal of Hydrology $385,120-131$.

6. Heikurainen L. 1967. Effect of cutting on the ground water level on drained peatlands. In: W.E. Sopper \& E.S. Corbett (Eds.) Int. Symp. on Forest Hydrol (August 29-September 10), Pergamon Press, Oxford, 345-354.

7. Henriksen A., Kirkhusmo L.A. 2000. Effects of clear-cutting of forest on the chemistry of a shallow groundwater aquifer in southern Norway. Hydrology and Earth System Sciences, 4(2), 323-331.

8. Jaszczak R. 1999. Monitoring lasów. Wydawnictwo AR Poznań, pp. 212.
9. Kondracki J. 2011. Geografia regionalna Polski. Wydawnictwo Naukowe PWN, Warszawa, pp. 444.

10. Kosturkiewicz A., Czopor S., Korytowski M., Stasik R., Szafrański Cz. 2001. Charakterystyczne stany wód gruntowych w glebach siedlisk leśnych w górnej partii zlewni Rowu Rakowskiego i ich związki ze stanami wody w cieku. Roczniki AR w Poznaniu, Leśn. 39, 135-148.

11. Kosturkiewicz A., Czopor S., Korytowski M., Stasik R., Szafrański Cz. 2002. Stany wody gruntowej i siedliska w małej zmeliorowanej zlewni leśnej. Roczniki AR w Poznaniu, Seria Melioracje i Inżynieria Środowiska, 338 (22), 41-53.

12. McCaughey J.H. 1985. A radiation and energy balance study of mature forest. Boundary-Layer Meteorology 32, 1-24.

13. Moore R.D., Wondzell S.M. 2005. Physical hydrology and the effects of forest harvesting in the Pacific Northwest: A review. Journal of American Resources Association, August, 763-784.

14. Operat glebowo siedliskowy i fitosocjologiczny LZD Siemianice, 1999. Zakład Usług Ekologicznych i Urządzeniowo Leśnych Poznań.

15. Plan urządzania lasu Nadleśnictwa Doświadczalnego Siemianice AR w Poznaniu, 1994. Katedra Urządzania Lasu Akademii Rolniczej w Poznaniu.

16. Radler K., Oltchev A., Panferov O., Klinck U., Gravenhorst G. 2010. Radiation and temperature responses to a small clear-cut in a spruce forest. The Open Geography Journal 3, 103-114.

17. Raport o stanie lasów w Polsce 2013. Centrum Informacyjne Lasów Państwowych. Warszawa 2014, pp. 103.

18. Sławska M. 2006. Możliwość wykorzystania fauny glebowej w monitoringu ekosystemów leśnych. Studia i Materiały Centrum Edukacji Przyrodniczo Leśnej, Warszawa, t. 8. z. 4(14), 184-192.

19. Sławski M. 2006. Co możemy zyskać pozostawiając kępy starodrzewu na zrębach zupełnych. Studia i Materiały Centrum Edukacji Przyrodniczo Leśnej, Warszawa, t. 8, z. 1 (11), 45-56.

20. Swank W.T., Vose J.M., Elliott K.J. 2001. Longterm hydrologic and water quality responses following commercial clearcutting on mixed hardwoods on a southern Appalachian catchment. Forest Ecology and Management 143, 163-178.

21. Trousdell K.B., Hoover M.D. 1955. A change in ground water level after clearcutting of loblolly pine in the Coastal Plain. Journal of Forestry 53, 493-498.

22. Zielony R., Kliczkowska A. 2012. Regionalizacja przyrodniczo-leśna Polski 2010. Centrum Informacyjne Lasów Państwowych. Warszawa, pp. 356. 